\author{
Magdalena Szczyrbak \\ Jagiellonian University in Kraków
}

\title{
Well, Don't These Two Look Dapper! Epistemological Positioning on Celebrity Gossip Websites
}

\begin{abstract}
Akin to stereotype, gossip is a transmission mechanism which fulfils persuasive functions, but which does not seek to answer questions about the genuineness of the transmitted information or its anchoring in reality other than the reality created during the communication process (Wagner 2006: 39). Such is also the case with online celebrity gossip, in which writers recruit various strategies to vary the epistemic strength of their assessments and to claim or disclaim responsibility for the accuracy of the provided information. Given the foregoing, basing on English and Polish linguistic material, this article investigates elements of epistemological positioning (Bednarek 2006) which underlie the construction of online celebrity news in two languages lacking grammaticalised systems of evidentiality. To this end, the study outlines the main strategies related to the communication of knowledge and identifies the resources used for the construal of (un)certainty in this type of discourse. The sources of evidence analysed in the study include: "Perception/Inference," "General knowledge," "Proof," "Obviousness," "Unspecified," "Hearsay" and "Mindsay," based on which diverse English and Polish EP markers are discussed. As the findings expose, rather than offer solid evidence, the authors of both sets of articles rely chiefly on perception, inference and hearsay, showing little epistemic commitment and decreasing the informative value of their reports.
\end{abstract}

\section{Keywords}

celebrity gossip, celebrity news, epistemicity, epistemological positioning, evidentiality, gossip websites, hearsay, media discourse

\section{Streszczenie}

Plotka, która jest zbliżona do stereotypu, stanowi mechanizm transmisji o funkcjach perswazyjnych, jednak nie próbuje odpowiedzieć na pytania o prawdziwość czy fałsz samego przekazu, ani o jego umocowanie w rzeczywistości innej niż ta, która jest budowana w procesie komunikacji (Wagner 2006: 39). Twierdzenie to dotyczy także internetowych plotek o gwiazdach, których autorzy stosują rozmaite strategie umożliwiające różnicowanie mocy epistemicznej formułowanych osądów, a także sygnalizujące, czy biorą oni odpowiedzialność za prawdziwość przekazywanych informacji. Uwzględniając powyż- 
sze ustalenia, $\mathrm{w}$ badaniu przeanalizowano elementy pozycjonowania epistemologicznego (Bednarek 2006) w artykułach plotkarskich pochodzących z bruk-portali napisanych w językach angielskim i polskim, tj. w językach nieposiadających gramatycznej kategorii ewidencjalności. W szczególności zwrócono uwagę na strategie przekazywania wiedzy, w tym na znaczniki związane z konstruowaniem (nie)pewności w badanym dyskursie. Analizą objęto następujące kategorie źródeł wiedzy: „Percepcja/Inferencja”, „Wiedza ogólna”, „Dowód”, „Oczywistość”, „Nieokreślone źródło wiedzy”, „Pogłoska” i „Referowane doświadczenie mentalne", na podstawie których wyodrębniono najczęstsze znaczniki w językach angielskim i polskim. Wyniki badania pokazują, że zarówno autorzy artykułów o gwiazdach napisanych w języku angielskim, jak i tych w języku polskim stosują głównie znaczniki odnoszące się do percepcji i inferencji, a także te sygnalizujące, iż źródłem informacji jest pogłoska. To z kolei sugeruje, że autorzy artykułów o celebrytach nie wykazują dużego zaangażowania epistemicznego oraz że ich teksty mają niską wartość informacyjną.

\section{Słowa kluczowe}

bruk-portale, epistemiczność, ewidencjalność, media brukowe, pozycjonowanie epistemologiczne, serwisy plotkarskie, portale plotkarskie, plotki

\section{Introduction}

Nowhere, as it seems, is the "generation" of content more evident than in the ubiquitous media, including the digital realm of the Internet. Given the abundance of interactive platforms, thanks to which information can spread uncontrollably, and at an unprecedented rate, questions are often raised about the authority and competence of those who create online content and the quality and reliability of the content itself. Unsurprisingly, a large body of linguistic scholarship reflects interest in issues related to the online dissemination of specialist and non-specialist knowledge and the linguistic marking of the reliability of such knowledge. The discourse of celebrity gossip, or celebrity news, has also attracted some attention, with scholars investigating such aspects as: promotion of the cult of celebrity (Breeze 2009), social values in celebrity news (Gorin and Dubied 2011) or evidential strategies in celebrity gossip blogs (Sánchez Cuervo 2014), to name but a few of them. Building on earlier research and, in particular, combining insights from sociological and discourseanalytic studies, this article reveals how authors of online celebrity news signal authority and entitlement to knowledge. Put differently, the study demonstrates how authors of online celebrity gossip articles articulate epistemic assessments and how they orient themselves towards the information they provide. In doing so, it follows the view that " $[t]$ here is an intuitive link between evidence and its recruitment in support of speaker commitment or judgement, particularly when that judgement involves the making of strong assertions" (Hoye 2008: 155). 


\section{Epistemological positioning}

Situated within the broader frame of evidentiality and epistemicity research, this empirical work draws on the concept of epistemological positioning (EP), i.e. "the linguistic expression of assessments concerning knowledge," proposed by Bednarek (2006). ${ }^{1}$ Following Chafe (1986) and Biber et al. (1999), Bednarek (2006: 637-638) explains that epistemological positioning (i.e. claims to knowledge) encompasses: basis of knowledge (evidentiality); certainty of knowledge (epistemic modality); (un)expectedness of knowledge (mirativity) ${ }^{2}$ and extent (limitation) of knowledge. ${ }^{3}$ As regards evidentiality, which is of greatest relevance to the current analysis, it should first be noted that although different accounts of this phenomenon can be found in the literature, two main approaches are dominant. According to the narrow view, evidentiality refers only to grammaticalised elements marking the type of evidence and this view is followed in research on languages other than English (see, e.g., Faller 2002; Aikhenvald 2004). The broad definition, on the other hand, suggests that the term evidential entails more than just the morphological marking of evidence; rather, it is argued, it subsumes other means of marking the source of information as well as reflects the author's assessment of the source of information. This approach is adopted by some linguists studying English (see, e.g., Chafe 1986). Acknowledging that the notion of EP subsumes evidentiality, ${ }^{4}$ Bednarek stresses that various expressions of evidentiality are associated with diverse pragmatic functions. A similar view is held by Mushin (2001: 82), who says that the "[c]hoice of epistemological stance, and the linguistic strategies used to express it, also rely on the speaker's rhetorical purpose, the extent to which they want to claim authority over information, and their immediate interactive goals." With regard to the certainty of knowledge, i.e. epistemic modality, being the second dimension of EP which is relevant here, Bednarek (2006: 638) observes that it can "either be directly expressed through the use of epistemic

${ }^{1}$ Acknowledging that the concept of knowledge is not easily defined, Bednarek (2006: 655) uses this term to denote speakers'/writers' awareness of true or false information to which they refer in their propositions.

${ }^{2}$ Mirativity is defined as the linguistic expression of surprise, ranging from primary interjections to more complex structures at the utterance level. For a fuller account of this phenomenon, see, for instance, DeLancey (1997) or Peterson (2010, 2016).

${ }^{3}$ The extent of knowledge can be marked by adverbs (e.g. generally) or prepositional phrases (e.g. in most cases) (Bednarek 2006: 638).

${ }^{4}$ Justifying her choice of the term epistemological positioning, Bednarek (2006: 637) points out that, firstly, it derives from the Greek word epistēmē meaning "knowledge" (rather than just evidence) and, secondly, that the (narrow) use of the term evidentiality allows researchers to refer to a specific subcategory of EP. Accordingly, whenever the adjective "epistemological" is used in this article, it refers to Bednarek's EP model. The adjectives "epistemic" and "evidential," on the other hand, indicate two subdomains which are subsumed by the overarching notion of "epistemological positioning." 
modal expressions (may, perhaps, must) or indirectly marked by evidential expressions." ${ }^{\prime 5}$ At the same time, she notes that while there is a connection between the type of evidence and the certainty of knowledge, there is no direct correlation between the two (Bednarek 2006: 638).

Applying the EP model in an analysis of news discourse, Bednarek (2006: 642) - following Sinclair (1988) and Hunston (2000) - introduces the notion of embedded talk and distinguishes between averral and attribution. Put differently, she draws a line between the author's own assertions (averral) and language which is derived from someone else (attribution). She notes as well that averral and attribution may be identified within the same utterance, since, in fact, "every attribution is embedded within an averral" (Hunston 2000: 179). To see this more clearly, consider the following example: "2015 equals Mommy, Daddy, Carmen and a special guest star.... Alec tweeted." In this case, even though a third party ("Other" = Alec) is the source of the embedded proposition, it is the writer ("Self") himself who is responsible for attributing the proposition to a particular source (here: Alec). In other words, the writer avers the entire utterance.

Another distinction made by Bednarek (2006: 646) is that between sourcing (i.e. identifying the Sayer, Senser or Experiencer) and evidentiality (basis of knowledge). In her view, bases of evidence include: "Perception," "General knowledge," "Proof," "Obviousness," "Unspecified," "Hearsay" and "Mindsay" (Bednarek 2006: 644). ${ }^{6}$ As regards averrals, in turn, Bednarek (2006: 647) observes that these can be classified either as based averrals (or, using Hunston's (2000) terminology, sourced averrals) or non-based averrals. Based averrals, she argues, indicate in some way the origin of knowledge without attributing it to any specific source, i.e. Other, as illustrated by the following example: "Chelsea threatened to quit Instagram after they censored her, but apparently she found it in her heart to move on and keep on posting nudes (...)." In this instance of a based averral, apparently indicates the writer's inference, that is his/ her interpretation of the available evidence. A non-based averral, on the other hand, can be illustrated by the following assertion: "DiCaprio and Garrn have been dating since May 2013," in the case of which the author does not index in any way the source of the reported information.

Bednarek's EP model will be applied in the ensuing analysis of celebrity news articles excerpted from British and Polish gossip websites.

${ }^{5}$ Cf. Dendale and Tasmowski's (2001) discussion on the relation between epistemicity and evidentiality. Even though, as they claim, "indicating the source of information is conceptually different from indicating the speaker's assessment of the reliability of information," the distinction between the two notions is not always obvious (Dendale and Tasmowski 2001: 341).

${ }^{6}$ These categories will be explained in detail in the Section 3. 


\section{Epistemological positioning on gossip websites: Evidence from English and Polish}

It is no surprise that celebrity gossip, or celebrity news, ${ }^{7}$ which has populated cyberspace in recent years, generates much online traffic and ensures high clickability figures. The gossiping itself has roots in oral communication, and as such, it predates rumours disseminated online. Viewed from a sociological perspective, gossip, as proposed by Wagner (2006: 39), is a transmission mechanism which fulfils persuasive functions and which does not seek to answer questions about the genuineness of the transmitted information or its anchoring in reality other than the reality created during the communication process. Equally noteworthy is the observation that traditional gossip can take the form of a conjecture, suggestion, judgement, libel or slander (Wagner 2006: 41) and, further, that it involves disclosure of non-public information, circulating in different versions, which occurs in group communication (Matusewicz 1998, quoted in Wagner 2006: 42). It cannot go unnoticed either that while prototypical gossip is a dynamic and spontaneous communicative event, gossip which has been written down is carefully edited. In this case, the author can, for instance, foreground selected elements, suggest the preferred reading of the message or even conceal the actual source of information (Wagner 2006: 40). Needless to say, more often than not, the reliability of the information is of secondary importance (Wagner 2006: 40). At the same time, somewhat paradoxically, authors aim at strengthening the veracity of the content they provide resorting to various discursive mechanisms. One of them involves the simulation of multivocality, i.e. the citing of alleged witnesses of reported events, attribution of information to well-known and respected persons, or even signing articles with made-up names, all of which result in the generation of "synthetic" or "quasinews" (Mateja 2011: 57-58). ${ }^{8}$ Notwithstanding the above, however, it needs to be acknowledged that although ethically questionable, gossiping performs a number of social functions and it is a way of shaping social reality (Wagner 2006). ${ }^{9}$

${ }^{7}$ It is interesting to note that while Polish portals such as pomponik.pl or pudelek.pl are referred to as portale plotkarskie ('gossip websites'), serwisy plotkarskie ('gossip platforms') or even bruk-portale ('tabloid websites'), similar British portals (e.g. uk.eonline.com, ok.co.uk) position themselves not only as providers of "celebrity gossip," but also as platforms with "entertainment news" and "celebrity news," thus, perhaps, keeping up the appearances of reporting reliable information.

${ }^{8}$ Mateja (2011: 58) uses Godzic's (2007: 45-46) terminology referring to celebrity news as niby-zdarzenia ('quasi-news'), niby-fakty ('quasi-facts') and syntetyczne newsy ('synthetic news').

${ }^{9}$ In her discussion of the social role of gossiping, Wagner (2006: 53) stresses, for instance, the affinity between gossip and social stereotyping. Drawing on Quasthoff (1973), she observes that stereotype is a logical judgement which, though unverified, ascribes specific properties or types of behaviour to a certain group of people or, conversely, denies the same. At the same time, she notes that this form of judgement tends to involve emotional evaluation. Regarding gossip, Wagner (2006: 54) also asserts that it serves as in-group or out-group identification, and that, therefore, it often targets "the Other," seen as a source of uncertainty or a threat. 
Given the foregoing considerations, I assumed that online celebrity gossip would be rife with instances of epistemological marking indicating a low level of certainty. To pinpoint the loci of uncertainty in this kind of discourse, I collected 25 celebrity news articles from the British website uk.eonline.com ${ }^{10}$ and 25 celebrity gossip articles from the Polish website pomponik.pl (totaling app. 16,500 words). The articles were chosen randomly out of the articles including celebrities' names and published between 2012 and 2014. It also needs to be added that the analysis was not conceived as an exhaustive description of epistemic markers in celebrity news. Instead, it sought to compare the possible realisations of individual EP marker categories in English and Polish, the two languages lacking grammaticalised systems of evidentiality. Another vital consideration were the divergent conceptualisations of epistemic markers in English and Polish; still, it was expected that the findings would demonstrate a considerable degree of comparability. ${ }^{11}$ In examining the types of EP marking in the celebrity gossip articles, the following questions were addressed: 1) What is the basis of the author's (or third party's) knowledge? and 2) How (un)certain is this knowledge? The results of the analysis are reported below. ${ }^{12}$

\subsection{Perception}

The first of the categories to be explored is that of "Perception," encompassing mental perception or inference (e.g. seem, look, appear) as well as sensory perception (e.g. look, see, visibly, audibly) and "showing" (e.g. reveal, show, betray, confirm), which, it is admitted, can shade into one another (Bednarek 2006: 640). In the data analysed, the "Perception" category was represented by the greatest variety of examples. ${ }^{13}$ In particular, it emerged that the authors of celebrity news frequently relied on verbs describing visual perception, in the case of which several patterns were observed. To start with, the verbs were used in agentless structures, making it impossible for the reader to distinguish between the Sayer and the Experiencer (that is, in SFL-terms, between the participant responsible for the verbal process and the participant who is engaged

${ }^{10}$ The website has changed its address. Currently, it is available at: www.eonline.com/uk.

${ }^{11}$ Cf. Rozumko's (2016) contrastive description of epistemic adverbs in English (seen as a heterogeneous discourse category) and modal particles in Polish (seen as a distinct word class). In her study, Rozumko (2016: 196) stresses that epistemic modality is both language- and culture-specific and, consequently, that epistemic expressions are categorised differently crosslinguistically. Referring to English and Polish adverbial epistemics, she concludes, however, that even though "the counterparts of individual epistemic adverbs in the two languages remain to be established," her findings suggest that there is enough comparability "to constitute a solid basis for a contrastive study" (Rozumko 2016: 211).

${ }^{12}$ It should also be clarified that quoted speech was excluded from the analysis.

${ }^{13}$ For more examples of EP markers attested by the data, see Appendix 1. 
in the mental process). ${ }^{14}$ Note, for instance, the deployment of the visual perception verb see in (1). Using the passive structure "the actress was seen," the author does not mention the person who actually "saw" the star featured in the article. Likewise, in (2) and (3), including the verb look, the Experiencer remains unidentifiable.

(1) Instead of showing off her signature blond hair, the actress was seen walking around with a brunette wig on.

(2) It looks like the 39-year-old is standing in front of a helicopter and her friends in the background seem to care very little about the fact that's [sic] she got her boobs out, basically framed by her backpack.

(3) Madonna’s children Lourdes and Rocco look so grown up as they playfully kiss each other on vacation.

Similar patterns involving references to visual perception were noted in the Polish data. In (4), for instance, the structure "nie sposób nie zauważyć" does not identify the Experiencer. By the same token, in (5), in the case of the assertion "Fakt' był ostatnio świadkiem," it is not clear who actually witnessed the described situation, as only the name of the tabloid is provided. Interestingly, neither the passive (e.g. byt widziany), nor the past participle (e.g. widziano) of the verbs widzieć/zobaczyć ('see') was the preferred choice in the Polish data, where only one instance of "można go było zobaczyć" ('he could be seen') was noted.

(4) Nie sposób nie zauważyć, że odkąd Zamachowski stracił głowę dla Moniki Richardson, traci też przyjaciół.

'It cannot go unnoticed that since Zamachowski lost his heart for Monika Richardson, he's been losing his friends as well.'

(5) "Fakt" był ostatnio świadkiem dość zabawnej sytuacji.

"'Fakt" has recently witnessed quite a funny situation.'

Another strategy identified in the English-language material was that of using mental perception verbs in the imperative, encouraging readers to become Experiencers themselves by looking at the photos or videos provided by the author (this strategy was, however, not attested by the Polish data). As (6) and (7) indicate, visual material was used to "authenticate" the accompanying text. However, despite the tangible "evidence" being provided and despite the author's attempt to impose the preferred interpretation, readers may not be sure about the context in which this "evidence" was obtained and its relevance to the information provided in the article.

${ }^{14}$ For an explication of the SFL-model of transitivity, involving the mutual interaction of processes, participants and circumstances, see, e.g., Halliday (1985). 
(6) Leonardo DiCaprio's girlfriend Toni Garrn parties with his ex-girlfriend Gisele Bündchen-See the pic!

(7) Tori Spelling gives update on feud with Mom Candy: "There's not much of a relationship"-Watch!

Also meaningful was the adoption of the we-perspective in both sets of articles, indicating a collective Experiencer, rather than a sensing individual. Relying on this strategy, the writer, again, denies any personal accountability for the accuracy of the information. For instance, in (8), basing on auditory evidence ("sounds like"), the author implies that the actor in question has decided on one role rather than the other and that this piece of news is too exciting for "us" (i.e. the tabloid) to keep it "to ourselves." By analogy, in (9), it becomes clear that "the surrounding snow" is not the only piece of evidence available to "us," based on which "we" claim that the temperature in the celebrity's nude picture was low. A similar strategy can be seen in the Polish example in (10), where the plural form "czytamy" is used.

(8) Sounds like Schwimmer is trading in "Pivot!" for "Acquit!" (Sorry, that one was just too good to keep to ourselves!)

(9) It's not just the surrounding snow that's telling us how cold the temperature must be in Chelsea Handler's latest Instagram pic.

(10) “W pobliżu nie było jednak wolnych miejsc. Cóż miała zrobić? Zielińska porzuciła auto na zakazie parkowania" - czytamy.

"'There were no free parking spaces in the area. What was she supposed to do? Zielińska left her car in a 'no parking' area," as we read.'

Beside visual perception marking, other epistemological signals involved mental perception or inference. In the English-language data, this group of markers included, for instance, the verbs seem and appear. Regarding the role of "it appears", as exemplified by (11), it should be explained that it marks an averral in which the basis of knowledge is "inside" the Self (Bednarek 2006: 648). ${ }^{15}$ In the same vein, the phrase "they seem to be," as shown in (12), indicates that the author bases his/her assertion on his/her own perception rather than a basis of knowledge found "outside" the Self. Similar observations can be made with regard to apparent, apparently and seemingly, as illustrated by (13) and (14), in the case of which, it can be argued, the bases of knowledge are not "construed as external and publicly accessible," but rather as "the writer's own subjective experience" (Bednarek 2006: 648). ${ }^{16}$ As the data bore out,

${ }^{15}$ In Rooryck's (2001: 128) classification, in turn, it appears is found in the category of "unspecified source/circumstantial inferential."

${ }^{16}$ It should be explained that in the English-language modality research, various categorisations of these markers are proposed. For instance, Simon-Vandenbergen and Aijmer (2007: 172) 
the epistemic strength of such averrals was in some cases attenuated by the co-occurrence of mental perception/inference markers, as exemplified by (14).

(11) And as Banderas carries on after his split, it appears Griffith is also moving forward with her life.

(12) The actor said he's never done drugs, which King found somewhat surprising given how prevalent they seem to be in Hollywood.

(13) Chelsea threatened to quit Instagram after they censored her, but apparently she found it in her heart to move on and keep on posting nudes.

(14) In May, Candy seemingly reignited her apparent feud with Tori when she wrote about her strained relationship with her daughter in her memoir Candy At Last.

In the Polish material, predictably, equivalent verbs were attested, namely: zdawać się ('seem'), wygladać ('look') and sprawiać wrażenie ('appear,' 'give the impression of'), which, too, indicated the basis of knowledge inside the Self and, consequently, a low certainty of the propositional content (see (15), (16) and (17)).

(15) Piosenkarka zdaje się nie widzieć problemu w tym, że przenosząc się do innego kraju, odseparuje dziecko od ojca.

'The singer seems not to see any problem in the fact that by moving to a different country, she will separate the child from its father.'

(16) Wygląda na to, że dla dawnej pomocy domowej Natalii Kukulskiej i byłej menedżerki Dody nadeszły tłuste lata!

'It seems that Natalia Kukulska's former domestic help and Doda’s former manageress is facing plentiful years!'

(17) Artystka przez cały dzień sprawiała wrażenie zadowolonej i cieszącej się z [sic] życiem.

'The artist seemed to be happy and enjoying her life all day.'

As regards the choice of modal adverbs in the Polish dataset, ${ }^{17}$ it was found that the role of apparently was performed by najwidoczniej (literally: 'most

describe apparently (alongside evidently) as a hearsay evidential "referring to what people say or what is known." In Hoye's (1997: 68) classification, similarly, apparently is referred to as a "hearsay particle." Huddleston and Pullum (2002: 768), on the other hand, list apparently together with evidently, seemingly, doubtless and presumably in the group of "quasi-strong" modal adverbs.

17 Discussing English modality, Simon-Vandenbergen and Aijmer (2007: 83-84) classify modal adverbs of certainty into: epistemic, evidential, expectation and speech-act adverbs, corresponding for the most part to Chafe's (1986) classification of evidentials based on degrees of reliability, source of knowledge, mode of knowing and knowledge matched against verbal resources and expectations. In Polish accounts of epistemic phenomena, on the other hand, equivalent expressions are described as epistemic particles. These, as Grochowski et al. (2014: 34-36) propose, may be subdivided into: hypothetical particles, inferential particles, particles 
visibly'), whereas najwyraźniej (literally: 'most clearly') corresponded functionally to the English clearly. ${ }^{18}$ At this point, it should be clarified that while in Polish widocznie ('apparently', 'clearly'), najwidoczniej ('apparently,' '(most) clearly') and najwyraźniej ('(most) clearly') have epistemic readings, wyraźnie ('clearly') operates only as an adverb of manner.

(18) Najwidoczniej znudziło im się już ukrywanie swojego uczucia. 'Apparently, they were already fed up with hiding their feeling.'

(19) Podwójna "randka" przyniosła najwyraźniej efekty... 'The "double" date clearly brought results...'

The next group of perception/inference markers included devices marking likelihood or probability, such as likely and probably ${ }^{19}$ in English and wielce prawdopodobne ('highly probable, 'highly likely') and prawdopodobnie ('probably', 'likely') in Polish, all reflecting the author's own conviction rather than external evidence. Relevant examples are shown in (20), (21) and (22).

(20) It's likely that Bündchen will attend Monday's Met Gala-will she have another run-in with Garrn?

(21) Edyta Górniak (42 1.) prawdopodobnie nie wystąpi podczas imprezy sylwestrowej we Wrocławiu. Powód? Władze Telewizji Polskiej nie chcą spełnić jej żądań!

'Edyta Górniak (42) probably won't appear during the New Year's party in Wrocław. The reason? The Polish state television authorities do not want to satisfy her wishes!'

(22) Jest bowiem wielce prawdopodobne, że Łukasz Nowicki nie przyklaśnie jej pomysłowi...

'Because it is highly probable that Łukasz Nowicki won't applaud her idea...'

Returning to the English-language data, probability was also expressed by the structure to be going to, as illustrated by (23), where the author predicts (based on the evidence presented in the remaining portions of the gossip article) that the year 2015 will be unusual for the Baldwin family. Since no

allowing disagreement and the possibility that the proposition is not true, confident particles, polemic particles, confirmatory particles, particles of conviction, referring particles and particles excluding the possibility that conflicting statements may be true (translation after Rozumko 2016: 207-208).

${ }^{18}$ However, in Bednarek's (2006) EP model, clearly falls within the category of "Obviousness" rather than "Perception."

19 The adverb probably is linked to medium certainty and it is positioned between certainly (marking high certainty) and possibly (marking low certainty). In Polish, similarly, prawdopodobnie is a hypothetical epistemic particle linked to the speaker's/writer's awareness of his/ her knowledge. 
corresponding structure is used in Polish, wyglada na to, że seems to be its closest equivalent. $^{20}$

(23) The year 2015 is going to be an extra special one for the Baldwins!

Moving on to epistemic modal verbs, which were also linked to varied degrees of probability, it was observed that while must, may, could and might were deployed in the English-language data to express a cline of certainty, in the Polish dataset only the third person singular of móc ('may') was found. ${ }^{21}$ The epistemic uses of may, could and might can be seen in (24), (25) and (26), whereas może ('(he/she) may') is exemplified by (27). Needless to say, all of these instances point to the author's inference as the source of information, thus having no (or, at best, low) informative value. Further still, although in Polish, the more tentative forms mógłby, mogłaby, etc. were not used, it was observed that the epistemic strength of individual utterances with może was in some cases weakened by the co-occurring hedging devices, as illustrated by (27), where może is followed by "mniej więcej za jakieś."

(24) Leonardo DiCaprio's days as a bachelor may be numbered.

(25) So what makes this twosome so intriguing? It could have something to do with the fact that Banderas is twenty years older than Kimpel.

(26) Leonardo DiCaprio might be ready for marriage: "It's gonna happen when it's gonna happen."

(27) (...), bo mąż może wrócić mniej więcej za jakieś 12 lat!

'(...), 'cos her husband may come back more or less in some 12 years!'

It should also be observed that not all occurrences of może were inflected verb forms, as in (27), since in some instances może operated as an epistemic particle meaning 'maybe' or 'perhaps', as in (28). Beside the epistemic particle może, chyba $a^{22}$ (functionally corresponding to 'probably, 'apparently', 'seem' or 'appear') was also attested. ${ }^{23}$ The low degree of epistemic commitment indexed by chyba, involving the author's understanding that the proposition may not be true, is neatly exemplified by (29) and (30). The two sentences, again,

${ }^{20}$ Another possible translation would be zanosi się na to, że, which, however, was not found in the Polish data.

${ }^{21}$ The Polish equivalent of must, i.e. musieć, occurred only in deontic contexts.

${ }^{22}$ The modal particle chyba has been discussed, for instance, in Bałabaniak (2005) and Rozumko $(2015,2016)$.

${ }^{23}$ In Grochowski et al.s (2014: 61-67) classification, both może and chyba belong to particles allowing disagreement and the possibility that the proposition is not true (other particles in this category include: bodaj, bodajże and być może). 
instantiate the author's subjective assessments and not statements of fact based on verifiable evidence which might be affirmed or disproved.

(28) Może dlatego, że uważa Łukasza Nowickiego za... „niedzielnego tatusia”.

"Maybe because she thinks that Eukasz Nowicki is a ... "Sunday daddy."

(29) Po pewnym czasie Zielińska jednak się opamiętała i chyba zdała sobie sprawę, że może należałoby auto przeparkować i nie blokować drogi...

'However after some time Zielińska came to her senses and she probably realised that maybe it would be necessary to move her car not to block the road...'

(30) Maja Sablewska (34 l.) chyba w końcu odnalazła swoje miejsce w show-biznesie. 'It seems that Maja Sablewska (34) has eventually found herself in showbiz.'

Modal particles aside, equally relevant to epistemological positioning was the mieć (have) + infinitive construction found in the Polish data. With no formal equivalent in English, this structure may be interpreted as meaning: 1) to be expected to/to be supposed to; 2) supposedly/allegedly and 3) to be to do sth. Note, for instance, the use of this construction in (31) and (32), where it serves as a distancing mechanism decreasing the epistemic strength of the utterance. By reporting that "do zdarzenia miało dojść 14 grudnia" in (31), the author disclaims responsibility for the accuracy of this information. Likewise, in (32), the writer only suggests that the photographs published by one of the weeklies "miały dowodzić" that the featured stars were together. Obviously, being opinions rather than factual statements, such utterances do not make the author liable for reporting untrue information.

(31) Do zdarzenia miało dojść 14 grudnia na jednej z imprez, gdy para została sama. 'The event allegedly took place on the $14^{\text {th }}$ of December at one of the parties, when the couple was alone.'

(32) Niedawno jeden z tygodników opublikował zdjęcia, które miały dowodzić, że jednak są razem.

'It was not so long ago that one of the weeklies published photos which supposedly proved that they were together after all.

The last group of markers to be discussed in the "Perception" category includes exclamations and declaratory questions implying the preferred answer and presenting presuppositions as accepted facts. Imitating speech (where they would most likely be said with rising intonation), such questions introduced a dialogic, conversational style and, given the broader context in which they appeared, they may plausibly be interpreted as ironic or sarcastic utterances, whose aim was to mock or ridicule the celebrities. ${ }^{24}$ Consider, for instance, the

${ }^{24}$ This, however, may not be supported by "hard" evidence, as no prosodic marking is indicated in the articles and the analyst can rely only on the contextual clues found in the co-text. 
question in (33), implying that the featured star believes that she does not have to observe the Highway Code (to substantiate the claim, the author reports that the star illegally parked her car) ${ }^{25}$

(33) Kolejna gwiazda, która sądzi, że kodeks drogowy jej nie obowiązuje?

'Another star that believes that the Highway Code does not apply to her?'

Turning now to the English data, similar presuppositions were presented also in the form of exclamations, as illustrated by the example in (34), introducing a conversational style and guiding the reader towards the preferred interpretation.

(34) Well don't these two look dapper!

Summing up, in light of the foregoing, it can be justifiably argued that the extensive presence of perception/inference markers - in particular those that fail to identify the Experiencer - indicates that authors of celebrity gossip articles tend to rely on low certainty markers which decrease the epistemic strength of the information they report.

\subsection{Hearsay/Mindsay}

Naturally, not only perception/inference markers, but also hearsay/mindsay markers may involve a low degree of the author's epistemic commitment. Associated with attribution, they indicate knowledge based on a third party's linguistic expression, i.e. "Hearsay," or a representation of a third party's (imagined) thoughts, i.e. "Mindsay" (Bednarek 2006: 643). As anticipated, both sets of articles provided ample evidence of such attributions, in the case of which three issues were examined: the choice of reporting verbs, references to sources (naming strategies) and the use of hearsay adverbs/particles, which, it was assumed, operated as linguistic clues contributing "toward the user's understanding of how much credibility can be attached to individual propositions and whether the information comes from the first-hand or second-hand sources" (Rubin 2010: 535).

Regarding the deployment of reporting verbs, it was found that both in English and in Polish the neutral verbs say/tell and mówić/powiedzieć were preferred. ${ }^{26}$ Other verbs included, for instance: add, ask, admit, describe, reveal and continue in English and twierdzić ('claim'), stwierdzić ('note,' 'conclude'),

${ }^{25}$ Given the strongly implied confirmation of the proposition and the presence of the mental-state verb believe, this interrogative sentence can also be interpreted as an example of "Mindsay" (cf. Section 3.2).

${ }^{26}$ In his discussion of news discourse, Bell (1991: 206) observes that say is "the canonical neutral speech verb." In her analysis of evaluation in media texts, Chen (2004), similarly, lists say and tell among the neutral verbal processes (as opposed to, e.g., announce and explain, described as positive verbal processes, or deny and insist, described as negative verbal processes). 
wyznać ('confess'), zdradzić ('reveal'), przyznać ('admit') and donosić ('report') in Polish. It was, too, interesting to note that the Polish authors favoured verbs pointing to the revelatory nature of the disclosed details, possibly with the aim of increasing the newsworthiness of the reported content. In the English data, no such pattern was discovered.

Another aspect which resurfaced during the analysis of reporting verbs was that of the recurrent transitivity patterns. To be precise, it was established that while in English, more often than not, the celebrity performed the role of the agent (or 'doer') and the news medium that of the receiver (the celebrity-told-the$X$-medium schema), in the Polish texts, conversely, the as-the-X-medium-reports pattern emerged as more salient (see (36)). The celebrity-informs structure, on the other hand, was recognised both in English and Polish, as demonstrated by (37) and (38). Also noteworthy was the celebrity-told-me schema instantiated by two examples in the English texts, indicating the author's (i.e. the Sayer's) greater epistemic commitment, as in (39). In the Polish articles, such patterns were not confirmed, as the I-perspective was never employed (except for quoted speech).

(35) "He still has one of my dogs," Bündchen told Vanity Fair in 2009.

(36) Tygodnik “Gwiazdy” donosi, że Monika przestała już być despotyczną żoną i pozwala mężowi na kulinarne zachcianki.

"The weekly "Gwiazdy" reports that Monika is no longer a despotic wife and that she lets her husband indulge in his food cravings.'

(37) “Snowboard Legend!" she wrote on Instagram with a picture of her son's bruised arm.

(38) Psycholożka zaś na swym profilu na Facebooku żartuje, publikując posty sugerujące, że przygotowuje się do świąt!

'The psychologist, on the other hand, makes jokes on her Facebook profile, adding posts which suggest that she's getting ready for the holiday!'

(39) "Brad Pitt loves charity, he loves giving back and it was just as simple as that," she told me on the red carpet.

In examining the references to sources, in turn, it was discovered that in the Polish data unnamed sources were galore (most typically: informator ('informer'), przyjaciótka ('girlfriend'), osoba $z$ otoczenia ('someone close to', 'insider'), znajomy ('acquaintance'), as illustrated by (40). In the English celebrity news under study, such practices were not frequently pursued, with only single references to unnamed sources being identified, such as, for instance, "some were quick to judge" shown in (41) or "led many to believe" in (48). ${ }^{27}$ What is more, in the Polish data, attribution to gossip media or other untrustworthy sources such as, for

${ }^{27}$ Cf. Telus's (2001: 141, quoted in Wagner 2006: 54) discussion on group quantifiers and group stereotypes. 
instance, a fortune teller, was not uncommon (see, e.g., (36) and (43)). These attributions appeared to create a sense of multivocality, arguably increasing the epistemic strength of the reported news. The media cited in the English celebrity news, on the other hand, tended to include more respected sources (see, e.g., (35)).

(40) „Niebawem podjął decyzję, że zakończy ich znajomość. To była bezpośrednia przyczyna załamania Justyny" - zdradza osoba z jej otoczenia.

"He soon took the decision to end their relationship. This was the direct cause of Justyna's breakdown," as revealed by someone close to her.'

(41) While some were quick to judge the actress' look, the 45-year-old wasn't willing to remain silent on the conversation.

Another group of hearsay markers which emerged during the analysis included the adverb allegedly ${ }^{28}$ in English and the adjectives rzekomy/domniema$n y$ ('alleged') in Polish (the related adverb rzekomo ('allegedly') was not attested). Though used sparingly, they, too, acted as distancing devices, with which the authors admitted the unconfirmed status of the reported information. Relevant examples are shown in (42), (43) and (44).

(42) Brandi Glanville asks Andy Cohen about Joanna Krupass allegedly smelly vagina and LeAnn Rimes' housewife future.

(43) Wróżka w rozmowie $\mathrm{z}$ tabloidem nie chciała jednak odnieść się do rzekomej współpracy $z$ Górniak.

'In a conversation with the tabloid, the fortune teller did not want to comment on the alleged cooperation with Górniak.

(44) O domniemanym romansie aktorów media huczały wprawdzie od miesięcy, jednak oboje konsekwentnie zaprzeczali tym doniesieniom.

'It is true that the media have been abuzz with information about the actors' alleged affair for months, but the two have been consistently denying these reports.'

In the same vein, the particles ponoc ${ }^{29}$ and podobno ${ }^{30}$ (whose meanings are similar to those of 'supposedly,' 'reputably' or 'reportedly') in Polish and the

${ }^{28}$ In Swan's (1988) description of modal adverbs, allegedly and supposedly belong to the category of "distancing modal adverbs." In the same vein, Huddleston and Pullum (2002: 769) claim that allegedly absolves the speaker/writer "from responsibility for the residual proposition," adding that the latter has the status of an allegation and that the speaker/writer cannot confirm whether it is true.

${ }^{29}$ Laskowska (1993: 52f) describes ponoć as an epistemically neutral reportive term, whereas Korytkowska and Roszko (1997: 139) hold that ponoć implies doubt (after Wiemer 2006: 27). Socka (2015: 134), on the other hand, observes that ponoć "functions as a merely agnostic hearsay marker" and, further, that this particle marks "second-hand" propositions or "introduces pieces of general knowledge, marginal notes, or anecdotes."

${ }^{30}$ Cf. Wiemer's (2006: 20) description of podobno, rzekomo and jakoby. In his view, while the latter two combine hearsay and epistemic attitude (i.e. doubt), podobno does not necessarily have epistemic overtones. Nor does it convey the speaker's doubt in the trustworthiness of the 
adverb reportedly in English suggested that the details about the celebrities' lives were already part of the communal knowledge (see, e.g., (45), (46) and (47)). A similar function was performed by the structure mówi się ('it is said,' 'people say'), which, however, was found only in the Polish data.

(45) Do spotkania pary doszło podobno dzięki Agnieszce Szulim, która przyjaźni się z Kędzierskim.

'Supposedly, the meeting took place thanks to Agnieszka Szulim, who is Kędzierski’s friend.'

(46) Ową dziewczyną jest ponoć właśnie Ala!

'Ala is supposedly that girl!'

(47) The Interview, Seth Rogen and James Franco's fictional comedy about killing North Korea's dictator, is reportedly the reason behind the hack.

Turning now to "Mindsay" markers - which, it may be argued, are not unproblematic given the fact that other people's (i.e. the Senser's) thoughts or feelings are not always accessible to the Sayer - it was established that sentences with mental-state verbs such as fear, believe, understand or wierzyć ('believe'), marzyć ('dream') and domyślić się ('guess') could be seen as instances of mindsay (despite the conventional expectation that the quoted content has actually been uttered). ${ }^{31}$ Note, for instance, (48) and (49), where the authors purport to know what the fans think.

(48) Tori's tweet led many to believe the " 1 person" she is referencing is her mother, and during a recent appearance on Today, she hinted that speculation was indeed true (although she chose to stay mum on the specific details).

(49) Fani mistrzyni nart szybko domyślili się, że za uczuciowe niepowodzenia Kowalczyk odpowiedzialny jest dziennikarz redakcji sportowej.

'The skiing champion's fans quickly guessed that Kowalczyk's emotional turmoil was caused by a sports journalist.'

\subsection{Other bases of knowledge}

As became obvious during the analysis, in the dataset under study, perception/ inference and hearsay markers played a dominant role in epistemological positioning, while other types of marking seemed rather marginal. Such was the case,

original message. Socka (2015: 133), similarly, admits that rzekomo and jakoby share the hearsay meaning. However, as she notes, jakoby is preferred in persuasive contexts, while in the case of rzekomo, the speaker does not aim to persuade the hearer (given that he/she lacks access to the described state of affairs) (Socka 2015: 133-134).

${ }^{31}$ Notwithstanding the above, Bednarek (2006: 657) holds that it is theoretically valid to distinguish between "Hearsay" and "Mindsay," as this distinction is reflected in different attributing expressions. 
for instance, with references to the communal epistemic background shared by the author and the addressee. In fact, in the "General knowledge" category, only two markers were identified, that is it's no secret in English and wiadomo ('it is known,' 'it is no secret') in Polish, as illustrated by (50) and (51), accordingly.

(50) It's no secret Tori Spelling has had quite the dramatic year.

(51) Wiadomo jednak, że sam Łukasz cierpiał dlatego, że własnego ojca, aktora Jana Nowickiego, widywał tylko od święta.

'It is no secret, however, that Łukasz himself suffered because he saw his own father, the actor Jan Nowicki, only during holidays.'

Markers from the "Obviousness" category included clearly ${ }^{33}$ and naturally in English and oczywiście in Polish, as shown in (52), (53) and (54), respectively.

(52) Oh the visual! Songwriting and storytelling, two things Martin is clearly a natural at.

(53) Given that the magazine named her "Woman of the Year," it naturally asked the actress-director to reflect on the past 12 months.

(54) Rozstaniu pary towarzyszył oczywiście szum medialny.

'The couple's split-up received of course extensive media coverage.'

The "Unspecified" category, on the other hand, was represented by one verb, namely: turn out in English and okazać się in Polish (see (55) and (56)).

(55) As it turns out, Zellweger is hard at work filming her new movie Same Kind of Different as Me in Jackson, Miss.

(56) Okazało się, że o wiele lepiej niż na muzyce zna się na ciuchach!

'It turned out that she knows more about fashion than music!'

Finally, rather unsurprisingly, no examples from the "Proof" category were attested.

\section{Conclusions}

In sum, celebrity gossip articles written in English and Polish appear to share quite a number of epistemological positioning strategies. In particular, the

${ }^{32}$ It should be admitted, however, that references to general knowledge may lack explicit marking. Such instances are not addressed in detail here.

${ }_{33}$ As reported by Simon-Vandenbergen and Aijmer (2007: 199), clearly is linked to solid evidence and intellectual reasoning and as such, it lends authority to the statements made by the author. This may partly explain why this adverb was not favoured by the authors of celebrity news linked to low certainty and "emotivisation." 
study showed that in both datasets heavy reliance on perception/inference and hearsay markers was a common practice. On the other hand, the principal difference, it was noted, was that while the authors of the articles written in English seemed to avoid attribution to not-so-reliable media or unnamed sources, this was not the case in the Polish material. The Polish authors, conversely, chose to report, not infrequently, untrustworthy accounts provided by unnamed sources (informers, insiders or acquaintances) or other gossip media, thus circulating content of low informative value.

With reference to the individual EP categories, it was established that despite the relative diversity of EP markers and their fairly big accumulation in both datasets, many of the individual devices were attested by single or, at most, several occurrences (e.g. it appears, allegedly, wygląda na to ('it looks like'), domniemany ('alleged'). In contrast, somewhat expectedly, a different pattern was noted in the case of the reporting verbs say/tell/add and mówić/powiedzieć ('say')/dodać ('add'), which were attested by quite a few occurrences and, a bit less predictably, in the case of chyba ('probably', 'apparently'), ponoć ('reportedly', 'reputedly'), podobno ('reportedly,' 'reputedly') in Polish, which, too, were used repeatedly. As for the markers which were salient in the Polish data and which did not have their formal equivalents in English, these included modal particles może ('maybe'), chyba ('probably', 'apparently'), ponoć ('reportedly', 'reputedly'), podobno ('reportedly, 'reputedly'), najwidoczniej ('apparently'), najwyraźniej ('clearly') and the mieć ('have') + infinitive construction. As for the strategies employed only by the English-speaking authors, these included visual perception verbs in the imperative (e.g. see the pic!) as well as references to the first person singular (e.g. she told me). The we-perspective (e.g. we're glad to see, czytamy $w$ tygodniku ('as we read in the weekly')) and agentless structures (e.g. the actress was seen, można go było zobaczyć ('he could be seen')), in turn, were noted in both languages. It was also interesting to observe with regard to transitivity patterns that while in the English texts the celebritytold-the-X-medium pattern was more frequent, in the Polish articles the as-the$X$-medium-reports schema seemed to be preferred (although, admittedly, the celebrity-informs pattern was also attested). Beside perception/inference and hearsay marking, other bases of knowledge ("Mindsay," "General knowledge," "Obviousness," "Unspecified") appeared to be marginal, not to mention the "Proof" category, in the case of which no examples were found.

That being said, it may be concluded that the low epistemic strength of online celebrity news does not result from the frequent repetition of individual EP signals, but rather that it is the work of the overall accumulation of diverse perception/inference and hearsay markers and the concurrent, meaningful absence of "hard evidence." Other factors, which are not accounted for in Bednarek's EP model, but which, too, contribute to the recipient's perception of the reliability of online information include, for instance, accumulation of emotive and 
evaluative lexis, "chatty" style (presence of questions, exclamations and personal asides) as well as a "loud" website layout (use of vivid colours, choice of font type, close-ups foregrounding selected visual elements), all indicating sensationalism, rather than high-quality reporting. What is more, the very fact that the English articles were signed with their authors' names, while the Polish ones were published anonymously may partly explain why the authors' epistemic commitment seemed higher in the case of the English-language texts.

Finally, it should again be reiterated that the study reported here does not claim exhaustiveness. Nor does it attempt to provide a systematic comparison of epistemic or evidential markers in English and Polish. Instead, adopting a qualitative perspective, it identifies the numerous sites of uncertainty in online celebrity news, as evidenced by English and Polish, and explains their role in epistemological positioning in this type of discourse. Suffice it to say that the findings agree with what Clark (2010) observes about today's quality press witnessing a shift towards hearsay evidence and the reporting of knowledge which has been acquired by speculation. Plainly, celebrity news websites fit squarely into this trend, as they pursue similar reporting practices, avoiding references to solid, verifiable evidence and quoting unnamed or unreliable sources of information.

\section{References}

Aikhenvald Alexandra (2004). Evidentiality. Oxford: Oxford University Press.

BAŁABANiak Dagmara (2005). Właściwości semantyczne partykuł modalnych (chyba, pewnie, pewno, zapewne) a struktura tematyczno-rematyczna wypowiedzenia, $P o$ lonica XXIV-XXV, 229-244.

BednareK Monika (2006). Epistemological positioning and evidentiality in English news discourse: A text-driven approach. Text \& Talk 26(6), 635-660.

BeLL Allan (1991). The Language of News Media. Oxford: Blackwell.

Biber Douglas, Johansson Stig, Leech Geoffrey, Conrad Susan, Finegan Edward (1999). The Longman Grammar of Spoken and Written English. London: Longman.

BREEZE Ruth (2009). Tarnished stars: The discourses of celebrity in the British tabloid press. Odisea 10, 7-18.

ChAfe Wallace (1986). Evidentiality in English conversation and academic writing. In Evidentiality: The Linguistic Coding of Epistemology, Wallace CHAFE, Johanna Nichols (eds.), 261-272. Norwood, NJ: Ablex Publishing.

Chen Lily (2004). Evaluation in media texts: A cross cultural linguistic investigation. Language in Society 33(5), 673-702.

Clark Caroline (2010). Evidence of evidentiality in the quality press 1993 and 2005. Corpora 5(2), 139-160.

DelanCEy Scott (1997). Mirativity: The grammatical marking of unexpected information. Linguistic Typology 1, 33-52. 
Dendale Patrick, Tasmowski Liliane (2001). Introduction: Evidentiality and related notions. Journal of Pragmatics 33, 339-464.

FAller Martina (2002). Semantics and Pragmatics of Evidentials in Cuzco Quechua. Stanford, CA: Stanford University, $\mathrm{PhD}$ dissertation.

Godzic Wiesław (2007). Znani z tego, że sa znani. Celebryci w kulturze tabloidów. Warszawa: Wydawnictwa Akademickie i Profesjonalne.

Gorin Valérie, Dubied Annik (2011). Desirable people: Identifying social values through celebrity news. Media, Culture \& Society 33(4), 599-618.

Grochowski Maciej, Kisıel Anna, Żabowska Magdalena (2014). Słownik gniazdowy partykuł polskich. Kraków: Polska Akademia Umiejętności.

Halliday Michael Alexander Kirkwood (1985). An Introduction to Functional Grammar. London: Edward Arnold.

Hoye Leo (1997). Adverbs and Modality in English. London/New York: Longman.

Hoye Leo (2008). Evidentiality in discourse: A pragmatic and empirical account. In Pragmatics and Corpus Linguistics: A Mutualistic Entente, Jesús Romero-Trillo (ed.), 151-174. Berlin/New York: Mouton de Gruyter.

Huddleson Rodney, Pullum Geoffrey K. (2002). The Cambridge Grammar of the English Language. Cambridge: Cambridge University Press.

Hunston Susan (2000). Evaluation and the planes of discourse: Status and value in persuasive texts. In Evaluation in Text: Authorial Stance and the Construction of Discourse, Susan Hunston, Geoff Thompson (eds.), 176-207. Oxford: Oxford University Press.

KoRYtкоwsкA Małgorzata, Roszko Roman (1997). Gramatyka konfrontatywna bułgarsko-polska 6, part 2: Modalność imperceptywna. Warszawa: Slawistyczny Ośrodek Wydawniczy.

LAskowska Elżbieta (1993). Wartościowanie w języku potocznym. Bydgoszcz: Wydawnictwo WSP.

MAtejA Magdalena (2011). “Świat przedstawiony” zamiast obrazu rzeczywistości? Kreacyjny potencjał mediów brukowych. Oblicza komunikacji 4, 57-71.

MatusewiCz Czesław (1998). Plotka. In Encyklopedia psychologii, Włodzimierz Szewczuk (ed.), 405-408. Warszawa: Wydawnictwo Naukowe PWN.

Mushin Ilana (2001). Evidentiality and Epistemological Stance. Narrative Retelling. Amsterdam/Philadelphia: John Benjamins.

Peterson Tyler (2010). Examining the mirative and non-literal uses of evidentials. In Evidence from Evidentiality (Vol. 28), Tyler Peterson, Uli Sauerland (eds.), Vancouver: University of British Columbia Working Papers in Linguistics.

Peterson Tyler (2016). Mirativity as surprise: Evidentiality, information, and deixis Journal of Psycholinguistic Research 45(6), 1327-1357.

QuAsthoff Uta (1973). Soziales Vorurteil und Kommunikation. Eine Sprachwissenschaftliche Analyse des Stereotyps. Frankfurt am Mein: Fischer-Athenäum.

Rooryck Johan (2001). State of the article: Evidentiality, Part I. Glot International 5.4, $125-133$.

Rozumko Agata (2015). The pragmatic functions of modal particles: A non-native speaker's perspective on dictionary definitions of surely and for sure. In Within Language, Beyond Theories (Vol. III). Discourse Analysis, Pragmatics and Corpus Studies, Wojciech Malec, Marietta Rusinek (eds.), 97-114. Cambridge: Cambridge Scholars Publishing. 
Rozumko Agata (2016). Linguistic concepts across languages: The category of epistemic adverbs in English and Polish. Yearbook of the Poznań Linguistic Meeting 2, 195-214.

Rubin Victoria L. (2010). Epistemic modality: From uncertainty to certainty in the context of information seeking as interactions with texts. Information Processing and Management 46, 533-540.

Sánchez Cuervo Margarita Esther (2014). 'Not sure what is going on today:' Verbal evidential strategies in celebrity gossip blogs. Nordic Journal of English Studies 13(3), 33-53.

Simon-Vandenbergen Anne-Marie, Aijmer Karin (2007). The Semantic Field of Modal Certainty: A Corpus-based Study of English Adverbs. Berlin/New York: Mouton de Gruyter.

SinCLAIR John (1988). Mirror for a text. Journal of English and Foreign Languages 1, 15-44.

SockA Anna (2015). Polish particles of hearsay: Syntactic and textual distribution. In Studies on Evidentiality Marking in West and South Slavic, Björn Wiemer (ed.), 111-137. München: Verlag Otto Sagner.

Swan Toril (1988). Sentence Adverbials in English: A Synchronic and Diachronic Investigation. Oslo: Novus.

Telus Magdalena (2001). Stereotyp grupowy a predykacja. In Język a kultura. Stereotyp jako przedmiot lingwistyki, teoria, metodologia, analizy empiryczne (Vol. 12), Jerzy BARTMiński, Janusz Anusiewicz (eds.), 135-146. Wrocław: Towarzystwo Przyjaciół Polonistyki Wrocławskiej.

WAGNER Aleksandra (2006). Plotka jako narzędzie kształtowania rzeczywistości społecznej. Afera Rywina w dyskursie prasowym. Studia Socjologiczne 4, 39-67.

WiEMER Björn (2006). Particles, parentheticals, conjunctions and prepositions as evidentiality markers in contemporary Polish (a first exploratory study). Studies in Polish Linguistics 3, 5-67.

Instytut Filologii Angielskiej

Uniwersytet Jagielloński

Al. Mickiewicza 9A

31-120 Kraków

Poland

[magdalena.szczyrbak(at)uj.edu.pl] 


\section{Appendix 1}

Examples of EP markers found in the data

\begin{tabular}{|c|c|c|}
\hline $\begin{array}{c}\text { BASE OF } \\
\text { KNOWLEDGE }\end{array}$ & ENGLISH & POLISH \\
\hline \multirow[t]{6}{*}{$\begin{array}{l}\text { PERCEPTION/ } \\
\text { INFERENCE } \\
\text { (mental, visual } \\
\text { and auditory } \\
\text { perception/ } \\
\text { inference) }\end{array}$} & $\begin{array}{l}\text { see/spot/look/watch } \\
\text { was nowhere to be seen; } \\
\text { they look so grown up; } \\
\text { take a look!/watch!/see the pic!; } \\
\text { we're freezing just looking at her }\end{array}$ & $\begin{array}{l}\text { zauważyć ('notice')/zobaczyć } \\
\text { ('see')/być świadkiem ('witness') } \\
\text { można go było zobaczyć ('he could } \\
\text { be seen'); } \\
\text { "Fakt" był ostatnio świadkiem } \\
\text { ("Fakt" has recently witnessed) }\end{array}$ \\
\hline & 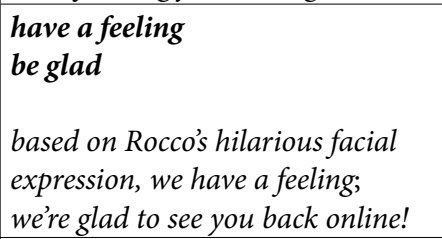 & \\
\hline & & $\begin{array}{l}\text { znać ('know') } \\
\text { znając Monikę, nie pozostawi } \\
\text { tego bez komentarza ('knowing } \\
\text { Monika, she won't leave it without } \\
\text { a comment') }\end{array}$ \\
\hline & $\begin{array}{l}\text { it looks like/it sounds like } \\
\text { it looks like a whole lot of } \\
\text { snowboarding; } \\
\text { sounds like Schwimmer is trading }\end{array}$ & $\begin{array}{l}\text { zdaje się ('it seems')/wygląda na } \\
\text { to ('it looks like') } \\
\text { zdaje się nie widzieć ('seems not to } \\
\text { see'); } \\
\text { wygląda na to, że ('it looks like') }\end{array}$ \\
\hline & $\begin{array}{l}\text { it appears/apparent/apparently } \\
\text { it appears Griffith is also moving } \\
\text { forward; } \\
\text { her apparent feud; } \\
\text { apparently she found it in her heart }\end{array}$ & $\begin{array}{l}\text { najwidoczniej ('apparently')/ } \\
\text { najwyraźniej ('clearly') } \\
\text { najwidoczniej znudziło im się ('they } \\
\text { apparently got bored with'); } \\
\text { jest już najwyraźniej pewna ('she is } \\
\text { clearly certain') }\end{array}$ \\
\hline & $\begin{array}{l}\text { seem to care very little; } \\
\text { seemingly reignited }\end{array}$ & $\begin{array}{l}\text { sprawiać wrażenie ('give the } \\
\text { impression of')/wydawać się } \\
\text { ('seem') } \\
\text { artystka sprawiała wrażenie } \\
\text { zadowolonej ('the artist seemed to } \\
\text { be happy'); } \\
\text { wydawało się, że znany aktor } \\
\text { wyciska z siebie siódme poty ('it } \\
\text { seemed that the well-known actor } \\
\text { worked his muscles') }\end{array}$ \\
\hline
\end{tabular}




\begin{tabular}{|c|c|c|}
\hline $\begin{array}{c}\text { BASE OF } \\
\text { KNOWLEDGE }\end{array}$ & ENGLISH & POLISH \\
\hline \multirow[t]{6}{*}{$\begin{array}{l}\text { PERCEPTION/ } \\
\text { INFERENCE } \\
\text { (mental, visual } \\
\text { and auditory } \\
\text { perception/ } \\
\text { inference) }\end{array}$} & $\begin{array}{l}\text { sure/for sure } \\
\text { definitely }\end{array}$ & $\begin{array}{l}\text { pewnie/zapewne/z pewnościa } \\
\text { ('surely', 'for sure') } \\
\text { nie ma watpliwości ('there's no } \\
\text { doubt') } \\
\text { Zbyszek zapewne odetchną } z \text { ulga! } \\
\text { ('Zbyszek will surely breathe a sigh } \\
\text { of relief!'); } \\
\text { nie ma już chyba wątpliwości, że } \\
\text { ('there is probably no doubt that') }\end{array}$ \\
\hline & $\begin{array}{l}\text { probably/likely } \\
\text { be going to } \\
\\
\text { you'll probably find; } \\
\text { it's likely that Bündchen will attend; } \\
\text { she's going to have one heck of an } \\
\text { introduction }\end{array}$ & $\begin{array}{l}\text { prawdopodobnie ('probably')/ } \\
\text { najprawdopodobniej ('most } \\
\text { probably') } \\
\text { niewykluczone ('it may even be', } \\
\text { 'perhaps') } \\
\\
\text { prawdopodobnie nie wystapi } \\
\text { ('probably won't appear'); } \\
\text { Przed Justyna kolejny sezon } \\
\text { narciarski, niewykluczone, ze ostatni } \\
\text { ('Justyna is facing the next skiing } \\
\text { season, perhaps the last one') }\end{array}$ \\
\hline & $\begin{array}{l}\text { may/can/could } \\
\text { must } \\
\text { days as a bachelor may be } \\
\text { numbered; } \\
\text { it could have something to do with; } \\
\text { Leonardo DiCaprio might be ready } \\
\text { for marriage; } \\
\text { it must be quite nipple-y }\end{array}$ & $\begin{array}{l}\text { móc ('may', 'can') } \\
\text { może się więc dość mocno sparzyć } \\
\text { ('so he may be really sorry'); } \\
\text { nie może być inaczej ('it can't be any } \\
\text { other way') }\end{array}$ \\
\hline & $\begin{array}{l}\text { maybe } \\
\text { see, maybe Lourdes was just trying }\end{array}$ & $\begin{array}{l}\text { może ('maybe,' 'perhaps') } \\
\text { może dlatego, że uważa ('maybe } \\
\text { because she thinks') }\end{array}$ \\
\hline & & $\begin{array}{l}\text { chyba ('probably', 'maybe', } \\
\text { 'apparently') } \\
\text { chyba w końcu odnalazła ('she } \\
\text { seems to have eventually found') }\end{array}$ \\
\hline & $\begin{array}{l}\text { be supposed to } \\
\text { That Happy Days episode was } \\
\text { supposed to be the "biggest piece of } \\
\text { s- -t." }\end{array}$ & $\begin{array}{l}\text { mieć (have) + infinitive } \\
\text { ('allegedly', 'supposedly') } \\
\text { do zdarzenia miało dojść ('the event } \\
\text { allegedly took place'); } \\
\text { zdjęcia, które miały dowodzić } \\
\text { ('photos which supposedly proved') }\end{array}$ \\
\hline
\end{tabular}




\begin{tabular}{|c|c|c|}
\hline $\begin{array}{c}\text { BASE OF } \\
\text { KNOWLEDGE }\end{array}$ & ENGLISH & POLISH \\
\hline $\begin{array}{l}\text { PERCEPTION/ } \\
\text { INFERENCE } \\
\text { (mental, visual } \\
\text { and auditory } \\
\text { perception/ } \\
\text { inference) }\end{array}$ & $\begin{array}{l}\text { Exclamations/declaratory } \\
\text { questions } \\
\text { Alec Baldwin punches out } \\
\text { paparazzo?!; } \\
\text { Well don't these two look dapper! }\end{array}$ & $\begin{array}{l}\text { Exclamations/declaratory } \\
\text { questions } \\
\text { Ich polsko-włoskim rozmowom nie } \\
\text { będzie konca! ('There will be no } \\
\text { end to their Polish-Italian talks!'); } \\
\text { Alicja Bachleda-Curuś ma romans } \\
\text { ze znanym dziennikarzem!? ('Alicja } \\
\text { Bachleda-Curuś is having an affair } \\
\text { with a well-known journalist!?') }\end{array}$ \\
\hline \multirow[t]{5}{*}{ HEARSAY } & $\begin{array}{l}\text { Reporting verbs } \\
\text { says/said, tells/told (me), } \\
\text { announced, added, asked, tweeted, } \\
\text { admitted, reveals/revealed, } \\
\text { described, explained, recalled, } \\
\text { shared, continued, } \\
\text { ranted, gushed }\end{array}$ & $\begin{array}{l}\text { Reporting verbs } \\
\text { mówi/mówiła ('says', 'she said'), } \\
\text { powiedział ('he said'); } \\
\text { twierdzi ('claims')/stwierdziła ('she } \\
\text { noted/concluded'); wyznała ('she } \\
\text { confessed'), zdradza ('reveals'), } \\
\text { przyznat ('he admitted'); donosi } \\
\text { ('reports'), dodaje ('adds'), wyjaśnia } \\
\text { ('explains'); relacjonuje ('reports') }\end{array}$ \\
\hline & $\begin{array}{l}\text { Attribution to named sources } \\
\text { Portman recently spoke to the New } \\
\text { York Magazine; } \\
\text { according to the Oscar-winning } \\
\text { actress }\end{array}$ & $\begin{array}{l}\text { Attribution to named sources } \\
\text { agentka celebrytki stwierdziła ('the } \\
\text { celebrity's agent noted'); } \\
\text { mówi Robert Myśliński ('says } \\
\text { Robert Myśliński') }\end{array}$ \\
\hline & $\begin{array}{l}\text { Attribution to unnamed sources } \\
\text { (some, many, source, insider) } \\
\text { a source tells E! News that; } \\
\text { the insider added }\end{array}$ & 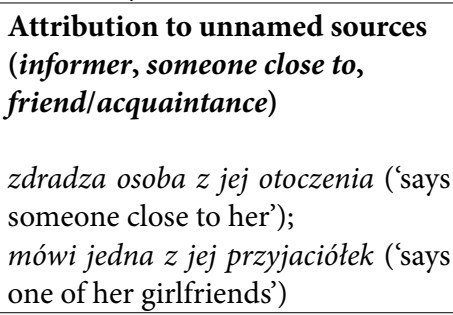 \\
\hline & $\begin{array}{l}\text { Reference to celebrities' reports } \\
\text { in other media } \\
\text { the actress, 39, told the Radio Times; } \\
\text { Williams said on Good Morning } \\
\text { America }\end{array}$ & $\begin{array}{l}\text { Reference to celebrities' reports } \\
\text { in other media } \\
\text { napisała na swoim facebookowym } \\
\text { profilu ('she wrote on her Facebook } \\
\text { profile'); } \\
\text { aktorka na swoim blogu napisała } \\
\text { ('the actress wrote on her blog') }\end{array}$ \\
\hline & $\begin{array}{l}\text { Personal communication by } \\
\text { celebrities } \\
\text { she told me on the red carpet; } \\
\text { The Good Wife star told me on the } \\
\text { Emmys red carpet }\end{array}$ & \\
\hline
\end{tabular}




\begin{tabular}{|c|c|c|}
\hline $\begin{array}{c}\text { BASE OF } \\
\text { KNOWLEDGE }\end{array}$ & ENGLISH & POLISH \\
\hline \multirow[t]{5}{*}{ HEARSAY } & & $\begin{array}{l}\text { Reference to reports in gossip } \\
\text { media } \\
\text { jak donosza plotkarskie media ('as } \\
\text { gossip media report'); } \\
\text { tabloidy donosza od miesięcy } \\
\text { ('tabloids have been informing } \\
\text { about it for months'); } \\
\text { jak dowiedziat się „Super Express" } \\
\text { ('as “Super Express" found out') }\end{array}$ \\
\hline & & $\begin{array}{l}\text { Reference to gossip } \\
\text { krażyty plotki ('there were } \\
\text { rumours'); } \\
\text { w show-biznesie aż huczy od plotek } \\
\text { ('showbiz has been abuzz with } \\
\text { gossip'); } \\
\text { krąża prawdziwe legendy ('there are } \\
\text { true legends') }\end{array}$ \\
\hline & $\begin{array}{l}\text { allegedly } \\
\text { allegedly smelly vagina }\end{array}$ & $\begin{array}{l}\text { rzekomy/domniemany ('alleged') } \\
\text { nie chciała jednak odnieść się do } \\
\text { rzekomej wspótpracy ('however, } \\
\text { she didn't want to comment on the } \\
\text { alleged cooperation'); } \\
\text { o domniemanym romansie aktorów } \\
\text { ('about the actors' alleged affair') }\end{array}$ \\
\hline & $\begin{array}{l}\text { reportedly } \\
\text { is reportedly the reason behind the } \\
\text { hack }\end{array}$ & $\begin{array}{l}\text { ponoć/podobno ('supposedly' } \\
\text { 'reputably', 'reportedly') } \\
\text { do spotkania pary doszło podobno } \\
\text { dzięki ('the meeting supposedly } \\
\text { took place thanks to'); } \\
\text { owq dziewczyna jest ponoć właśnie } \\
\text { Ala! ('Ala is reportedly that girl!') }\end{array}$ \\
\hline & & $\begin{array}{l}\text { mówi się ('it is said') } \\
\text { mówi się, że pocieszenia szukat ('it } \\
\text { is said that he sought consolation') }\end{array}$ \\
\hline
\end{tabular}




\begin{tabular}{|c|c|c|}
\hline $\begin{array}{c}\text { BASE OF } \\
\text { KNOWLEDGE }\end{array}$ & ENGLISH & POLISH \\
\hline MINDSAY & $\begin{array}{l}\text { fear } \\
\text { believe } \\
\text { understand } \\
\text { because he feared she could; } \\
\text { Tori's tweet led many to believe; } \\
\text { although she understands that her } \\
\text { kids are }\end{array}$ & $\begin{array}{l}\text { wierzyć ('believe') } \\
\text { mieć marzenie ('have a dream') } \\
\text { domyślić się ('guess') } \\
\text { dziennikarka głęboko wierzy, że } \\
\text { ('the journalist firmly believes } \\
\text { that'); } \\
\text { fani mistrzyni nart szybko domyślili } \\
\text { się, że ('the skiing champion's fans } \\
\text { quickly guessed') }\end{array}$ \\
\hline $\begin{array}{l}\text { GENERAL } \\
\text { KNOWLEDGE }\end{array}$ & $\begin{array}{l}\text { it is no secret } \\
\text { it's no secret Tori Spelling has had }\end{array}$ & $\begin{array}{l}\text { wiadomo ('it is no secret') } \\
\text { wiadomo jednak, że sam Łukasz } \\
\text { cierpiał ('it is no secret, however, } \\
\text { that Łukasz himself suffered') }\end{array}$ \\
\hline OBVIOUSNESS & $\begin{array}{l}\text { clearly } \\
\text { naturally } \\
\text { two things Martin is clearly } \\
\text { a natural at; } \\
\text { it naturally asked the actress- } \\
\text { director to reflect on } \\
\end{array}$ & $\begin{array}{l}\text { oczywiście ('of course') } \\
\text { rozstaniu pary towarzyszyt } \\
\text { oczywiście szum medialny ('the } \\
\text { couple's split-up received of course } \\
\text { extensive media coverage') }\end{array}$ \\
\hline UNSPECIFIED & $\begin{array}{l}\text { turn out } \\
\text { as it turns out, Zellweger is hard at } \\
\text { work }\end{array}$ & $\begin{array}{l}\text { okazać się ('turn out') } \\
\text { "Sablewskiej sposób na modę" } \\
\text { okazał się hitem ("Sablewskiej } \\
\text { sposób na modę" turned out to be } \\
\text { a hit') }\end{array}$ \\
\hline PROOF & No examples found & No examples found \\
\hline
\end{tabular}

